\title{
The Effects of the Factors Related to the Patient and the Disease on the Performance of Ablation Therapy in Patients with Differentiated Thyroid Cancer who have Received I-I3I Ablation Therapy
}

\author{
- 13 I Ablasyon Tedavisi Verilen Diferansiye Tiroid Kanseri Tanilı Hastalarda Hastaya ve Hastalığa Ait \\ Faktörlerin Ablasyon Başarisı Üzerine Etkileri
}

Tank ŞengözI, Erdem Sürücü2, Yusuf Demir3, Erkan Derebek ${ }^{4}$

I Ballkesir Government Hospital, Department of Nuclear Medicine, Balkesir, Turkey

2 Yüzüncü Yıl University, School of Medicine, Department of Nuclear Medicine, Van, Turkey

3/zzet Baysal Government Hospital, Department of Nuclear Medicine, Bolu, Turkey

${ }^{4}$ Dokuz Eylül University, School of Medicine, Department of Nuclear Medicine, Izmir, Turkey

\begin{abstract}
Objective: To investigate whether the factors related to the patient and the disease have any effect on the success of ablation therapy in patients with differentiated thyroid cancer who have received I-131 ablation therapy.

Material and Methods: All the patients with differentiated thyroid cancer were referred for 1-131 ablation therapy after thyroidectomy between July 2007 and September 2009. The patients had at least six months of follow-up. Age, gender, type of tumor, presence of capsule invasion, size of tumor, number of the tumors, localization of the tumor, invasion of thyroid capsule, lymph/vessel invasion, presence of metastatic lymph nodes, type of surgery, preablation values of thyroglobulin (Tg), AntiTg, TSH, surveys for the evaluation of metastatic disease, (thyroid and bone scintigraphy, neck and abdominal ultrasonography, chest and brain computerized tomography), administered dose, postablation I-131 whole body scan (WBS) and diagnostic I-131 WBS, neck USG, values of $\mathrm{Tg}$ and AntiTg at the $6^{\text {th }}$ month were recorded. The presence of residual thyroid activity on the 6 th month diagnostic I-131 WBS image was accepted as the criterion for ablation success.

Results: 191 patients with differentiated thyroid cancer were assessed in this study. The overall success rate of the first ablation therapy was $74.3 \%$. The success rate of the ablation therapy was $66 \%$ and $75 \%$ in metastatic group and non-metastatic group, respectively. Except the significant correlation between the number of pathologic lymph nodes and the success of ablation $(p=0.025)$, there was no other significant correlation between the patient/disease related factors and the success of ablation therapy.

Conclusion: Significant correlation between the number of the pathologic lymph nodes and the ablation therapy performance can also be due to statistical error because of the limited sample size. There was no significant correlation between other patient/disease related prognostic factors and the success of ablation therapy. (MIRT 2012;21:103-109)
\end{abstract}

Key words: Thyroid neoplasms, lodine radioisotopes, prognosis

\section{Özet}

Amaç: Diferansiye tiroid kanseri tanısı almış ve I-131 ablasyon tedavisi verilmiş hastalarda, hastaya ve hastalığa ait faktörlerin ablasyon başarısı üzerinde etkilerinin olup olmadığının araștırılmasıdır.

Gereç ve Yöntemler: Temmuz 2007- Eylül 2009 tarihleri arasında Dokuz Eylül Üniversitesi Tıp Fakültesi Nükleer Tıp ABD Radyonüklid Tedavi Polikliniği'ne başvuran, diferansiye tiroid karsinomu tanııı almış, total/totale yakın tiroidektomi yapılmıs ve I-131 ablasyon tedavisi verilmesi için refere edilmiş hastalar ve çalışma süresi içinde en az 6. ay kontrollerine gelen tüm hastalar değerlendirmeye alındı. Hasta dosyaları retrospektif olarak tarandı. Hastalara ait yaş, cinsiyet, tümör tipi, tümör subtipi, tümör kapsül varlığı ve invazyonu, tümör boyutu, tümör sayısı, tümör lokalizasyonu, tiroid kapsül ve lenf/damar invazyonu, metastatik lenf nodu varlığı, operasyon şekli, preablasyon Tiroglobulin (Tg), Anti-Tiroglobulin (ATG), Tiroid Stimule Edici Hormon (TSH), metastaz tarama için görüntülemeler (tiroid ve kemik sintigrafisi, boyun ve abdomen ultrasonografi, toraks ve beyin bilgisayarlı tomografisi), verilen doz, post ablasyon I- 131 tüm vücut taraması (TVT), 6. ayda diagnostik I-131 TVT, boyun USG, Tg, ATG sonuçları değerlendirildi. Tiroid lojunda rezidü saptanmayan hastalar 'ablasyon başarılı' , rezidü saptanan hastalar ise 'ablasyon başarısız' olarak kabul edildi.

Bulgular: Çalışmaya diferansiye tiroid karsinom tanılı 191 hasta alındı. Ablasyon başarıı \%74,3 olarak hesaplandı. Hastaların 15'inde (\%7,8) ablasyon öncesi metastaz saptanmışstı. Metastatik hastalarda ablasyon başarısı \%66 iken metastaz negatif grupta ise \% 75 idi. Patolojik lenf nodu sayısı ile ablasyon başarısı arasında anlamlı bir ilişki bulunurken $(p=0,025)$, diğer faktörler (lenf nodu sayısı, yaş, cinsiyet, tümör tipi, tümör odak sayısı, tiroid kapsül ve lenf/kan damar invazyonu vb.) ile ablasyon başarısı arasında anlamlı bir iliş̌ki saptanmadı.

Sonuç: Diferansiye tiroid kanser tanılı ve I-131 ablasyon tedavisi verilen hastalarda patolojik lenf nodu sayısı ile ablasyon başaı́ıı arasında anlamlı bir ilişki mevcuttur. Ancak bu bulgunun örneklem büyüklüğünün küçük olması nedeniyle istatistiksel hataya bağlı da olabileceği düşünülmüştür. Bu değişken dışında diğer prognostik faktörler ile ablasyon başarısı arasında anlamlı bir ilişki bulunamamıştır. (MIRT 2012;21:103-109)

Anahtar kelimeler: Tiroid tümörleri, iyot radyoizotopları, prognoz

Address for Correspondence: Tarık Şengöz MD, Balıkesir Government Hospital, Department of Nuclear Medicine, Balıkesir, Turkey Phone: +90 5321631342 E-mail: tariksengoz@yahoo.com.tr

Received: 17.10.2012 Accepted: 20.11.2012

Molecular Imaging and Radionuclide Therapy, published by Galenos Publishing. 


\section{Introduction}

Thyroid cancer is the one of rare type of cancers in humans that constitutes less than $1 \%$ of all cancers (1). However, it has the highest mortality rate among the endocrine cancers (2). Differentiated thyroid cancer (DTC) is evaluated and treated according to the prognostic factors. Many prognostic scoring systems (TNM, AMES, AGES, MACIS, etc.) have been developed for the evaluation. The purpose of the scoring systems is to make the separation of low-and high-risk patients. Mortality and recurrence rate is very low in patients with low-risk. 10-year and 20-year mortality rate in the high risk group is $20-30 \%$ and $40 \%$ (3). Prognostic factors include age, gender, type of surgical treatment, tumor size, tumor type, being multifocal / multicentric, thyroid capsule invasion, lymph/blood vessel invasion, lymph node (LNs) and distant metastases.

The efficacy of I-131 ablation therapy after surgery is still controversial, but it is reported that ablation therapy reduces morbidity and mortality. Mazzaferri et al. reported that recurrence rate after ablation was $16 \%$ in the patients with a tumor size greater than $1.5 \mathrm{~cm}$, multifocal, capsule or LNs invasion, on the other hand, the recurrence rate after TSH supression therapy was 38\%; mortality rate was $3 \%$ and $8 \%$, respectively in their study with 802 patients (4). The effect of the prognostic factors and patient characteristics on the success of ablation therapy was investigated in some studies, but there is still debate in the effect of prognostic factors and patient characteristics.

In this study, the effect of clinical and laboratory findings of the patient and the disease on the ablation success was investigated by the follow-up (6th month, 1st year, 2nd year) of patients who received ablation therapy after surgical treatment of DTC

\section{Material and Methods}

\section{Patients}

Patients who were diagnosed with DTC, treated with total and/or near-total thyroidectomy and referred for 1-131 ablation therapy between July 2007 and September 2009 were included in our study. Each patient was followed-up at least 6 months. Age, gender, tumor type, the presence of tumor capsule and tumor capsule invasion, tumor size, number of tumors, tumor localization, thyroid capsule and lymphatic / vascular invasion, the presence of LNs metastasis, type of surgery, pre-ablation Thyroglobulin (Tg), anti-thyroglobulin (ATG) and TSH values, imaging for metastatic screening (thyroid and bone scintigraphy, neck and abdominal ultrasonography, chest and brain CT), the administered dose, post-ablation 1-131 whole body scan (WBS) and diagnostic l-131 WBS, neck ultrasonography, Tg, ATG results at 6th months were recorded.

\section{Therapy and Follow-up}

Standard dose was administered to all patients: 100 $\mathrm{mCi}$ to the patients with low-risk and without LNs or distant metastasis, $150-175 \mathrm{mCi}$ to the patients with invasion to the thyroid capsule, lymph / blood vessels, surrounding soft tissue and without LNs or distant metastasis, 150-175 mCi to the patients with high risk and LNs metastasis at diagnosis, $200 \mathrm{mCi}$ to the patients with high risk and distant metastases that was detected with imaging modalities (bone scan, brain and chest $\mathrm{CT}_{\text {, neck }}$ and abdominal USG). $50 \mathrm{mCi}$ dose was given to 2 patients due to the large amount of residual tissue and $75 \mathrm{mCi}$ dose was given to 3 patients secondary to the diagnosis of microcarcinoma.

Patients were followed with thyroid function tests (TFT) for the regulation of suppression dose during the first 3 months. Ablation success was evaluated six months after therapy. During this period, Tg and ATG values one month after stopping T4 suppression therapy, neck ultrasonography and diagnostic WBS with $10 \mathrm{mCi}$ were obtained. The ablation success was evaluated according to the diagnostic WBS in the $6^{\text {th }}$ month. It was concluded that the patients without any residual uptake in the thyroid region in WBS were ablated successfully. Mild uptake in the thyroid region was evaluated as an unsuccessful ablation.

\section{Statistical Analysis}

Mann-Whitney $U$ test was used for the effect of these variables to the success of ablation because of the nonhomogeneous distribution. Chi-square test was used for the relationship between categorical variables and the success of ablation. In addition, logistic regression analysis was performed for the evaluation of the cumulative effects of these variables on the success of the ablation. In the univariate analysis method, two different models was created using the variables associated with the success of ablation and the variables identified in the literature associated with the success of ablation

The presence of the metastatic LNs (absent/present) was used in one of the models and the number of the metastatic LNs $(0-1,>2)$ was used in the other model. Furthermore, age, gender, tumor type, the number of tumor foci, thyroid capsule invasion, lymph / blood vessel invasion were added to the both models.

\section{Results}

Descriptive characteristics of 191 (150 Women, 41 Men; average age: $45 \pm 13$ years) patients are given in Table 1. Ablation therapy was successful in 142 of 191 patients (74.3\%) and unsuccessful in 49 of 191 patients (25.7\%). Significant difference was seen in the success of ablation between the patients with two or more metastatic LNs and 0-1 metastatic LNs $(p<0.05)$. Successful ablation was achieved in 138 patients (76.2\%), with 0-1 metastatic LN and in four patients (40\%) with two or more metastatic LNs.

The ablation success rate decreases with increasing number of metastatic LNs. Significant relationship was not found between the ablation success and the categorical variables that belong to the patient and disease (Table 2). Significant difference was not seen between the ablation 
success and the categorical variables that belong to the patient and disease. There was also no significant difference between the ablation success and the numeric variables $(p>0.05)$. The average and standart deviations of the numeric variables in the groups with successfull and unsuccessfull ablation were shown in Table 3.

\section{The Results of Multivariate Analysis}

Significant difference was found only for the number of metastatic LNs among all variables. Additionally, it was revealed that the ablation success rate reduces by $80 \%$ in the patients with one or more metastatic LNs (Table 4).

The Relationship Between the Success of the Ablation and $\mathrm{Tg}$ and ATG

The average $\mathrm{Tg}$ value at the 6th month was found as $9.3 \pm 43.3$ in the group with unsuccessful ablation and $1.9 \pm 14.4$ in the group with successful ablation. There was a significant relationship between the ablation success and $\mathrm{Tg}$ value at the $6^{\text {th }}$ month $(p<0.05)$. The average ATG value at the $6^{\text {th }}$ month was found as $21.5 \pm 6.8$ in the group with unsuccessful ablation and $30.5 \pm 40.8$ in the group with successful ablation. No significant relationship was found between the ablation success and ATG value in 6th month (Table 5). No significant relationship was seen between the degree of residual scale and some of categorical variables ( $p>0.05$ ) (Table 6).

\section{The Ablation Success in Patients with Metastatic and} Non-metastatic Disease Before the Therapy

There was no metastatic disease in 176 of 191 patients (\%91). Significant difference was not detected between the ablation success and categorical/numerical variables in patients with non-metastatic disease. Logistic regression model as a multivariate analysis method has been developed in order to see the cumulative effect of these factors to the success of ablation and there was no significant difference in this model (Table 7). High-dose I131 therapy (175 and $200 \mathrm{mCi}$ ) were given to ? of (15) 191 patients $(7.8 \%)$ with lymph node/distant metastasis before ablation therapy. There was no significant diference between the ablation success and categorical/numerical variables in the patients given high-dose, except the number of metastatic lymph nodes in neck ultrasonography.

\section{Discussion}

The main purpose of the $1-131$ ablation therapy is removing the residual tissue in the patients with DTC $(5,6)$. Microscopic tumor foci are eradicated as a result of ablation (6). The elimination of all residual tissue with ablation increases the sensitivity of WBS by increasing the accumulation of $1-131$ in the metastatic foci (7). Furthermore, ablation therapy also increases the sensitivity and specificity of $\mathrm{Tg}$ values that indicates the recurrent disease during follow-up (8). It has been reported that ablation therapy reduces recurrence, metastasis, and mortality rate dramatically $(4,6,9)$. There are many factors that affect the ablation success. It has been reported that absorption and transport of radioiodine to the thyroid cells,
NIS expression heterogeneity, the radiosensitivity of thyroid cell, TSH levels, the amount of residual tissue, the amount of the dose can affect the ablation success.

In this study, the ablation success was found as $74.3 \%$. There are different results for the ablation success in the studies. The ablation success was reported as $70-95 \%$ in the literature. Zidan et al. found the ablation success as $94 \%$ by giving 30-85 mCi dose in 238 patients and they also reported that there was no significant difference between doses (10). In the study with 149 patients, ablation success was found as $72.8 \%$ with the doses of $30-155 \mathrm{mCi}$ and they also indicated that the ablation success was better with doses higher than $50 \mathrm{mCi}$ (11). In our study, $72.8 \%$ of the patients were given $100 \mathrm{mCi}, 16.8 \%$ of the patients were given $150 \mathrm{mCi}, 6.3 \%$ of the patients were given $175 \mathrm{mCi}$, and $1.5 \%$ of the patients were given $200 \mathrm{mCi}$. There was no significant difference between the amount of the dose and the ablation success. Most of the literature reported that there was no significant difference in the ablation success between low-dose and highdose iodine $(12,13,14,15)$. Therefore, this difference may be secondary to the heterogeneity of NIS expression in residual tissue and as a result of this, the difference of iodine uptake in these patients (16).

In the present study, no significant difference was found between the ablation success, gender and average age of the patients and the results of this study are consistent with the literature $(17,18,19)$. In our study, ablation was successful in $74.7 \%$ of patients with papillary cancer and in $71.4 \%$ in patients with follicular cancer. There was no significant correlation between tumor type and the success of ablation.

In the present study, no significant difference was seen between the tumor size and the ablation success. While tumor diameter has significant effects on the recurrent disease, it has no effects on the success of ablation. Sirisalipoch et al. and JD Lin et al. showed that the tumor size did not affect the ablation success $(17,19)$.

There was no significant correlation between the ablation success and the presence of the thyroid capsule invasion. There is no data showing that relationship between the thyroid capsule invasion and success of ablation in the literature. However, Mazzaferi et al. showed that thyroid capsule invasion affects the therapy response and increases the mortality in their study with 1355 patients (20).

There was inverse and effective relationship between the ablation success and the number of metastatic lymph nodes in our study. Increasing the number of metastatic LNs (from 0 to 1 or from 1 to 2 ) reduces the ablation success by $80 \%$. In some studies, it has been reported that tumor metastasis to lymph nodes is an important prognostic risk factor in the recurrent disease and cancer-specific mortality. There are no studies including the explaination of this relationship in the literature. However, it has been known that NIS expression and iodine uptake are lower in the tumor foci and metastatic lymph nodes than the normal thyroid tissue (16). Kyoung So et al. showed NIS expression in the primary tumor focus (95\%) and metastatic lymph nodes (96\%). But, they reported that NIS glycoprotein was located in the cytoplasm and only 
Table 1. Descriptive characteristics and the Success of ablation

\begin{tabular}{|c|c|c|c|}
\hline Categorical variable & Groups & Number & $\%$ Value \\
\hline \multirow[t]{2}{*}{ Gender } & Women & 150 & 78.5 \\
\hline & Men & 41 & 21.5 \\
\hline \multirow[t]{2}{*}{ Tumor type } & Papillary & 170 & 89 \\
\hline & Follicular & 21 & 11 \\
\hline \multirow[t]{2}{*}{ The presence of thyroid capsule } & $(-)$ & 138 & 72.8 \\
\hline & $(+)$ & 53 & 27.2 \\
\hline \multirow[t]{3}{*}{ Tumor capsule invasion } & Capsule (-) & 138 & 72.3 \\
\hline & Capsule (+) Invasion (-) & 23 & $12(44)^{*}$ \\
\hline & Capsul e(+) Invasion (+) & 30 & $15.7(56)^{*}$ \\
\hline \multirow[t]{3}{*}{ The localisation of tumor focus } & One focus & 137 & 71.7 \\
\hline & Multifocal & 17 & 8.9 \\
\hline & Multicentric & 37 & 19.4 \\
\hline \multirow[t]{4}{*}{ The number of tumor foci } & 1 & 137 & 71.7 \\
\hline & 2 & 39 & 20.4 \\
\hline & 3 & 13 & 6.9 \\
\hline & 4 & 2 & 1.0 \\
\hline \multirow[t]{3}{*}{ Thyroid capsule invasion } & $(-)$ & 126 & 66 \\
\hline & Suspicious & 11 & 5.8 \\
\hline & $(+)$ & 54 & 28.2 \\
\hline \multirow[t]{2}{*}{ lymphatic invasion } & $(-)$ & 161 & 84.3 \\
\hline & $(+)$ & 30 & 15.7 \\
\hline \multirow[t]{2}{*}{ Vascular invasion } & $(-)$ & 164 & 85.9 \\
\hline & $(+)$ & 27 & 14.1 \\
\hline \multirow[t]{2}{*}{ Lymph Node Dissection } & $(-)$ & 27 & 12.6 \\
\hline & $(+)$ & 167 & 87.4 \\
\hline \multirow[t]{2}{*}{ Residual tissue in neck USG } & $(-)$ & 131 & 68.6 \\
\hline & $(+)$ & 60 & 31.4 \\
\hline \multirow[t]{5}{*}{ Pathological lymph node in neck USG } & 0 & 172 & 90.1 \\
\hline & 1 & 8 & 4.2 \\
\hline & 2 & 5 & 2.6 \\
\hline & 3 & 2 & 1.0 \\
\hline & 4 & 4 & 2.1 \\
\hline \multirow[t]{2}{*}{ Thyroid scintigraphy } & $(-)$ & 46 & 24.1 \\
\hline & $(+)$ & 145 & 75.9 \\
\hline \multirow[t]{2}{*}{ Metastasis in Bone scan } & $(-)$ & 179 & 93.7 \\
\hline & Suspicious & 12 & 6.3 \\
\hline \multirow[t]{3}{*}{ Metastasis in chest CT } & $(-)$ & 164 & 85.9 \\
\hline & Suspicious & 22 & 11.5 \\
\hline & $(+)$ & 5 & 2.6 \\
\hline \multirow[t]{2}{*}{ Metastasis in brain CT } & $(-)$ & 187 & 97.9 \\
\hline & Suspicious & 4 & 2.1 \\
\hline \multirow[t]{2}{*}{ Metastasis in abdomen USG } & $(-)$ & 189 & 99.0 \\
\hline & Suspicious & 2 & 1,0 \\
\hline \multirow[t]{6}{*}{ Ablation dose } & $50 \quad \mathrm{mCi}$ & 2 & 1.0 \\
\hline & $75 \quad \mathrm{mCi}$ & 3 & 1.6 \\
\hline & $100 \mathrm{mCi}$ & 139 & 72.8 \\
\hline & $150 \mathrm{mCi}$ & 32 & 16.8 \\
\hline & $175 \mathrm{mCi}$ & 12 & 6.3 \\
\hline & $200 \mathrm{mCi}$ & 3 & 1.5 \\
\hline \multirow[t]{2}{*}{ Success of ablation } & Unsuccessful & 49 & 25.7 \\
\hline & Successful & 142 & 74.3 \\
\hline
\end{tabular}

${ }^{\star}$ Capsule invasion rate in the patients with tumor capsule 
$15 \%$ of this was expressed in the basal membrane which might result in unsuccess ablation (21). In our study, since the ablation of residual tissue is evaluated, we thought that the lower rate in the success of treatment might be due to the microscopic tumor foci in residual tissue in the patient with metastatic lymph nodes (16).

Because the number of patients with metastatic LNs are relatively smaller than the number of patients without metastatic LNs (20 patients positive), false statistical results might be considered. Therefore, further studies are needed to support our findings.
Significant correlation was found between the Tg value at the 6 th month and the ablation success. The possibility of the ablation success decreases when Tg value increases. There are also a few studies supporting this finding in the literature $(18,19)$.

In the current study, it was shown that the detection of LN metastasis reduces the ablation success. It has been reported that metastasis can cause poor therapy response and poor prognosis (22). Ablation dose accumulates in both metastatic and residual tissue in patients with metastatis and higher doses that were preferred in order

Table 2. The relationship between the success of ablation and patients/disease releated factors (Categorical variable)

\begin{tabular}{|c|c|c|c|}
\hline \multirow[t]{2}{*}{ Categorical variable } & \multicolumn{2}{|c|}{ Success of ablation } & \multirow[t]{2}{*}{$\mathrm{p}$ Value } \\
\hline & Number & $\%$ & \\
\hline \multicolumn{4}{|l|}{ Gender } \\
\hline Men $(n=41)$ & 29 & 70.7 & 0.55 \\
\hline Women $(n=150)$ & 113 & 75.3 & \\
\hline \multicolumn{4}{|l|}{ Tumor type } \\
\hline Papillary (n=170) & 127 & 74.7 & 0.79 \\
\hline Follicular $(n=21)$ & 15 & 71.4 & \\
\hline \multicolumn{4}{|l|}{ The presence of tumor capsule } \\
\hline$(+)(n=53)$ & 39 & 75 & 1.0 \\
\hline$(-) \quad(n=138)$ & 103 & 74.1 & \\
\hline \multicolumn{4}{|l|}{ Invasion of tumor capsule } \\
\hline Capsule (-) (n=138) & 103 & 74.1 & 0.89 \\
\hline Capsule $(+)$, invasion $(-)(n=23)$ & 18 & 78.3 & \\
\hline Capsule $(+)$, invasion $(+)(n=30)$ & 22 & 73.3 & \\
\hline \multicolumn{4}{|l|}{ The localisation of tumor focus } \\
\hline One focus $(n=137)$ & 100 & 72.9 & 0,35 \\
\hline Multifocal $(n=17)$ & 15 & 88.2 & \\
\hline Multicentric $(n=37)$ & 26 & 70.3 & \\
\hline \multicolumn{4}{|l|}{ Invasion of thyroid capsule } \\
\hline$(-)(n=126)$ & 93 & 73.8 & 0.60 \\
\hline Suspicious ( $n=11$ ) & 7 & 63.6 & \\
\hline$(+)(n=54)$ & 42 & 77.8 & \\
\hline \multicolumn{4}{|l|}{ lymphatic invasion } \\
\hline$(-)(n=161)$ & 121 & 75.2 & 0.64 \\
\hline$(+)(n=30)$ & 21 & 70.0 & \\
\hline \multicolumn{4}{|l|}{ Vascular invasion } \\
\hline$(-)(n=164)$ & 122 & 74.4 & 1.0 \\
\hline$(+)(n=27)$ & 20 & 74.1 & \\
\hline \multicolumn{4}{|c|}{ The presence of of pathological LN in neck USG } \\
\hline$(-)(n=172)$ & 131 & 76.1 & 0.09 \\
\hline$(+)(n=20)$ & 12 & 60.0 & \\
\hline \multicolumn{4}{|c|}{ The number of pathological LN in neck USG } \\
\hline $0-1(n=181)$ & 138 & 76.2 & $0.02^{*}$ \\
\hline$>2(n=10)$ & 4 & 40.0 & \\
\hline \multicolumn{4}{|l|}{ Residual tissue in neck USG } \\
\hline$(-)(n=131)$ & 96 & 73.3 & 0.58 \\
\hline$(+) \quad(n=60)$ & 46 & 76.6 & \\
\hline
\end{tabular}


to provide ablation can be insufficient for the ablation however, statistical errors can not be excluded due to the low number of patients with metastases.

\section{Conclusion}

I-131 ablation therapy is a successful form of treatment that aims to destroy the remaining residual tissue after surgical treatment in the patients with differentiated thyroid cancer.
There is no significant correlation between the ablation success and age, gender, tumor type, presence and invasion of tumor capsule, thyroid capsule invasion, tumor size, number of tumor foci, the lymph / blood vessel invasion, metastatic lymph node and the presence of residual tissue in neck ultrasonography, the number of residual foci in thyroid scintigraphy, preablation TSH, Tg, and ATG values, the amount of the dose given to the patient. The success of ablation is independent from these variables.

Table 3. The relationship between the success of ablation and patients/disease releated factors (Quantative variables)

\begin{tabular}{|c|c|c|c|}
\hline \multirow[t]{3}{*}{ QUANTITATIVE VARIABLES } & \multicolumn{2}{|c|}{ THE SUCCESS OF ABLATION } & \multirow[t]{3}{*}{ p VALUE* } \\
\hline & \multicolumn{2}{|c|}{$(\mathrm{MEAN} \pm$ STANDART DEVIATION $)$} & \\
\hline & Ablation (-) & Ablation (+) & \\
\hline Tumor size & $20.8 \pm 17.7$ & $18.7 \pm 14.3$ & 0.53 \\
\hline The number of tumor focus & $1.4 \pm 0.7$ & $1.4 \pm 0.6$ & 0.87 \\
\hline The number of pathological LN & $0.4 \pm 1.1$ & $0.2 \pm 0.6$ & 0.09 \\
\hline Residual foci in thyroid scintigraphy & $1.6 \pm 1.3$ & $1.4 \pm 1.2$ & 0.31 \\
\hline Preablation $\mathrm{Tg}$ & $22.7 \pm 56.4$ & $12 . .7 \pm 41.1$ & $0 . .80$ \\
\hline Preablation ATG & $43.2 \pm 70.6$ & $54.7 \pm 115.6$ & 0.89 \\
\hline Preablation TSH & $70.6 \pm 30.5$ & $75.1 \pm 34.2$ & 0.29 \\
\hline The number of pathological LN in neck USG & $0.3 \pm 0.8$ & $0.2 \pm 0.7$ & 0.30 \\
\hline Residual foci in postablation WBS & $2.7 \pm 1.2$ & $2.4 \pm 1.3$ & 0.27 \\
\hline Ablation dose & $114.3 \pm 31.4$ & $113.6 \pm 26.7$ & 0.83 \\
\hline Age & $42.9 \pm 13.7$ & $45.7 \pm 12.7$ & 0.10 \\
\hline
\end{tabular}

Table 4. Multivariate analysis (logistic regression)

\begin{tabular}{|c|c|c|c|}
\hline VARIABLES & $p$ & OR & 95\% CONFIDENCE INTERVAL \\
\hline Number of pathological LN $(0-1,2<)$ & 0.02 & 0.20 & $0.05-0.82$ \\
\hline Presence of pathological LN & 0.20 & 1.96 & $0.68-5.61$ \\
\hline Age & 0.24 & 1.02 & $0.98-1.04$ \\
\hline Gender & 0.37 & 0.69 & $0.30-1.56$ \\
\hline Tumor type & 0.97 & 1.02 & $0.28-3.68$ \\
\hline Thyroid capsule invasion & 0.48 & 0.56 & $0.11-2.79$ \\
\hline Number of tumor foci & 0.77 & 0.92 & $0.54-1.55$ \\
\hline Lymphatic invasion & 0.55 & 0.64 & $0.15-2.75$ \\
\hline Blood vessel invasion & 0.73 & 1.30 & $0.28-6.00$ \\
\hline Constant & 0.37 & 1.85 & \\
\hline
\end{tabular}

Table 5. The relationship between the success of ablation and Tg/ATG values in $6^{\text {th }}$ month

\begin{tabular}{llrl}
\hline QUANTITATIVE VARIABLES & \multicolumn{2}{c}{ THE SUCCESS OF ABLATION } & p VALUE* $^{*}$ \\
\hline \multicolumn{2}{c}{ (MEAN \pm STANDART DEVIATION) } \\
Ablation $(-)$ & Ablation $(+)$ & $1.9 \pm 14.4$ & 0.04 \\
\hline Tg & $9.3 \pm 43.3$ & $30.5 \pm 40.8$ & 0.26 \\
\hline ATG & $21.5 \pm 6.8$ & &
\end{tabular}


Table 6. Descriptive findings of the degree of residual scale in the $1-131$ WBS in $6^{\text {th }}$ month

\begin{tabular}{lll}
\hline GROUPS & NUMBER & $\%$ VALUE \\
\hline 0=no residue & 142 & $\% 74.3$ \\
1=suspicious & 4 & $\% 2.0$ \\
2= Mild & 21 & $\% 11.2$ \\
3=Moderate & 14 & $\% 7.3$ \\
4=Clear & 10 & $\% 5.2$ \\
Total & 191 & $\% 100$ \\
\hline
\end{tabular}

Table 7. The results of multivariate analysis of metastasis in patients with non-metastatic disease

\begin{tabular}{lccc}
\hline VARIABLES & $p$ & OR & $\begin{array}{l}\text { 95\% } \\
\text { CONFIDENCE } \\
\text { INTERVAL }\end{array}$ \\
\hline $\begin{array}{l}\text { Number of pathological LN } \\
\text { (0-1, 2<) }\end{array}$ & 0.52 & 1.60 & $0.44-5.82$ \\
Presence of pathological LN & 0.17 & 1.02 & $0.99-1.05$ \\
Age & 0.99 & 0.99 & $0.39-2.54$ \\
Gender & 0.57 & 1.37 & $0.45-4.13$ \\
Tumor type & 0.59 & 0.77 & $0.30-1.96$ \\
Thyroid capsule invasion & 0.15 & 0.99 & $0.96-1.02$ \\
Number of tumor foci & 0.54 & 1.68 & $0.30-9.31$ \\
Lymphatic invasion & 0.85 & 0.84 & $0.14-5.04$ \\
Constant & 0.97 & 0.96 & \\
\hline $\begin{array}{l}\text { Variables in this model: the number of pathological lymph node (0-1 / 2<), age, } \\
\text { gender, tumor type, thyroid capsule invasion, number of tumor foci, lymph / blood } \\
\text { vessel invasion }\end{array}$ & \multicolumn{4}{l}{} \\
\hline
\end{tabular}

Significant correlation exists between the success of ablation and the number of metasatic lymph nodes. However, this finding can also be considered to be a statistical error due to the small sample size of the patients.

\section{References}

1. Junqueria LC, Carneiro J, Kelley RO. Basic Histology. Appleton\&Lange 1992;413-420.

2. Schlumberger MJ. Papillary and follicul thyroid carcinoma. N Engl J Med 1998;338:297-306.

3. Hay D. Papillary thyroid carcinoma. Endocrinol Metab Clin North Am 1990;19:545-576.

4. Mazzaferri EL, Kloos RT. Clinical review 128: Current approaches to primary theraphy for papillary and folliculer thyroid cancer. J Clin Endocrinol Metab 2001;86:1447-1463.

5. DeGroot LJ, Kaplan EL, McCormick M, Straus FH. Natural history, treatment and course of papillary thyroid cancer. J Clin Endocrinol Metab 1990:71:414-424.
6. Roelants V, Nayer PD, Bouckaert A, Beckers C. The predictive value of serum thyroglobulin in the follow-up of differentiated thyroid cancer. Eur J Nucl Med 1997;24:722-727.

7. Moser E, Fristch S, Braun S. Thyroglobulin and I-131 uptake of remaining tissue in patients with differentiated carcinoma after thyroidectomy. Nucl Med Commun 1988;9:262-266.

8. Spencer CA, Wang CC. Thyroglobulin measurement - techniques, clinical benefits and pitfalls. Endocrinol Metab Clin North Am 1995;24:841-863.

9. Dean DS, Hay ID. Prognostic indicators in differentiated thyroid carcinoma. Cancer Control 2000;7:229-239.

10. Zidan J, Hefer E, losilevski G, Drumea K, Stein ME, Kuten A, Israel O. Efficacy of I-131 ablation therapy using different doses as determined by postoperative thyroid scan uptake in patients with differentiated thyroid cancer. Int J Radiat Oncol Biol Phys 2004;59:1330-1336.

11. Bal C, Padhy AK, Jana S, Pant GS, Basu AK. Prospective randomized clinical trial to evaluate the optimal dose of 131 I for remnant ablation in patients with differentiated thyroid carcinoma. Cancer 1996;77:2574-2580.

12. Pilli T, Brianzoni E, Capoccetti $F$, Castagna MG, Fattori S, Poggiu A, Rossi G, Ferretti F, Guarino E, Burroni L, Vattimo A, Cipri C, Pacini F. A Comparison of $1850 \mathrm{MBq}(50 \mathrm{mCi})$ and $3700 \mathrm{MBq}(100 \mathrm{mCi})$ I-131 administered doses for recombinant thyrotropin-stimulated postoperative thyroid remnant ablation in differanted thyroid cancer. J Clin Endocrinol Metab 2007;92:3542-3546. Epub 2007 Jul 3.

13. Liel $Y$. Preperation for radioactive iodine administration in differantiated thyroid cancer patients. Clin Endocrinol (Oxf) 2002; 57:523-527.

14. Barbaro D, Boni G, Meucci G, Simi U, Lapi P, Orsini P, Pasquini C, Turco A, Mariani G. Recombinant human thyroid- timulating hormone is effective for radioiodine ablation of postsurgical thyroid remnants. Nucl Med Commun 2006,27:627-632.

15. Pacini F, Molinaro E, Castagna MG, Lippi F, Cecceralli C, Agate L, Elıse $\mathrm{R}$, Pınchera A. Ablation of thyroid remnants with $30 \mathrm{mCi}$ 131: A comparison in thyroid cancer patients prepared with recombinant human TSH or thyroid hormone withdrawal. J Clin Endocrinol Metab 2002;87:4063-4068.

16. Klain M, Ricard $M$, Leboulleux S, Baudin E, Schlumberger $M$. Radioiodine therapy for papillary and follicular thyroid carcinoma. Eur J Nucl Med Mol Imaging 2002;29 Suppl 2:S479-85. Epub 2002 May 9.

17. Sirisalipoch S, Buachum V, Tepmongkol S, Boonvisut S. Prospective randomized trial for evaluation of efficacy of low versus high dose I-131 for post operative remnant ablation in differantiated thyroid cancer. Chula Med J 2006:50:695-706.

18. Comtois R, Thériault C, Del Vecchio P. Assessment of the efficacy of Iodine-131for thyroid ablation. J Nucl Med 1993;34:1927-1930.

19. Lin JD, Kao PF, Chao TC. The effects of radioactive iodine in thyroid remnant ablation and treatment of well differantiated thyroid carcinoma. Br J Radiol 1998;71:307-313.

20. Mazzaferri EL, Jhiang SM. Long-term impact of initial surgical and medical therapy on papillary and follicular thyroid cancer. Am J Med 1994;97:418-428.

21. So YK, Son YI, Baek $\mathrm{CH}$, Jeong HS, Chung MK, Ko YH. Expression of Sodium-lodide symporter and TSH receptor in subclinical metastatic lymph nodes of papillary thyroid microcarcinoma. Ann Surg Oncol 2012;19:990-995. Epub 2011 Aug 31.

22. Chow SM, Law SC, Mendenhall WM, Au SK, Chan PT, Leung TW, Tong CC, Wong IS, Lau WH. Papillary thyroid carcinoma: prognostic factors and the role of radioiodine and external radiotherapy. Int J Radiat Oncol Biol Phys 2002;52:784-795. 